\title{
DEVELOPMENT, FABRICATION, AND PERFORMANCE EVALUATION OF INDIRECT MULTI- PORTIONED TYPE SOLAR DRYER FOR AGRICULTURAL PRODUCE
}

\author{
IJAZ UL HAQ ${ }^{1}$, HUSNAIN AZAM ${ }^{2}$, NIDA FIRDOUS ${ }^{3 *}$, MUHAMMAD MUDDASSIR ${ }^{1}$, AMNA SAHAR ${ }^{1}$, HAROON $^{2}$ \\ SALEEM ${ }^{1}$, MUHAMMAD USMAN $^{1}$, ADIL MAJEED ${ }^{4}$
}

${ }^{1}$ Department of Food Engineering, University of Agriculture, Faisalabad, Pakistan. , 2Institute of Home and Food Sciences, Government College University Faisalabad, Pakistan., ${ }^{3}$ Punjab Food Authority, Punjab Pakistan., ${ }^{4}$ National university of computer and emerging sciences. Email: nidafirdous88@gmail.com

Received: 20 July 2021, Revised and Accepted:28 August 2021

\section{ABSTRACT}

OBJECTIVE: The primary objective of this study was to minimize post-harvest damages and improve the handling of agricultural commodities. The secondary objective was to assess the performance of the dryer by varying inlet velocity of air on temperature, final moisture of the product, drying period, and drying rate

METHODS: The present research was carried out for the development, fabrication, and testing of a multi-portioned type solar dryer. The multiportioned dryer consisted of a collector unit, air storage chamber, drying cabins, and a chimney. A fan assembly was also attached at the inlet of the collector and at the outlet of the drying compartment to control the air velocity and to remove the moist air.

RESULTS: The data obtained from the experiments revealed that the maximum temperature elevation of $36.5^{\circ} \mathrm{C}$ was attained during a no-load test The results obtained after carrying out load tests revealed that the maximum drying rate of $47 \mathrm{~g} / \mathrm{hr}$ was achieved at the air inlet velocity of $3.2 \mathrm{~m} / \mathrm{s}$. The initial moisture content of $80.50 \%$ was brought down to $3.31 \%$ in five sunshine hours of 150 gram sliced potatoes. Each portion received air at varying speeds, and it was observed that the portion receiving air at the lowest speed had the maximum temperature.

CONCLUSION: The lowest temperature elevation was recorded for the portion receiving air at the highest speed. The dryer was also found to be suitable for the on-field practical application for the drying of perishable commodities.

Keywords: Drying; moisture; Agricultural commodities; solar dryer; perishable products

(C) 2021 The Authors. Published by Innovare Academic Sciences Pvt Ltd. This is an open access article under the CC BY license (http://creativecommons.org/licenses/by /4.0/] DOI: http://dx.doi.org/10.22159/ijags.2021v9i5.41847. Journal homepage: https://innovareacademics.in/journals/index.php/ijags

\section{INTRODUCTION}

Food is necessary along with water and air for all human beings. In developing countries rather than low production, food spoilage problems occur due to improper handling of fruits and vegetables. Immediate consumption of agricultural products is always less than agricultural produce. [1]. To meet the needs of consumers, there is very little supply of fruit throughout the year. This is mainly because almost all fruits are seasonal and difficult to store in their original form. This has led to their scarcity of availability which makes them inaccessible to most people in developing countries. [2]

Pakistan is mainly an agricultural country whose economy depends heavily on agricultural products, especially on fruits. Pakistan faces $40-50 \%$ postharvest losses annually. Some of the main factors contributing to such post-harvest losses are post-harvest diseases and poor post-harvest management. [3]

The losses during post-harvest handling of agricultural commodities have a big impact on the economy of developing countries. Postharvest losses can only be reduced by producing better quality products through efficient and drying methods readily available. Water is the main source of microbial growth in agricultural products with essential nutrients. Therefore, to avoid the proliferation of microorganisms, the product should be dried sufficiently to store product as long as possible [4].

There are three objectives for researching the drying practice in the food manufacturing sectors [5].

Profitable consideration: To reduce costs, increase the production capability for each unit of drying system, improve simple drying systems that are consistent and require a minimum workforce to reduce off-specification products

Environmental problems: To reduces the energy/fuel consumption within the drying process

Quality of Product: To accurately control, the moisture content of the product at the ending of the drying procedure, minimizing the chemical degradation reactions, and obtaining the desired color of the product [5]

The drying and dehydration of fresh products are one of the developments with the highest energy consumption in the food industry and a capable way to reduce post-harvest losses. The dehydration properties of dehydrated foods are critical, given the increased demand from consumers for processed products that retain more of their original characteristics. [6].

Agricultural producers continue to face the challenge of increasing the quantity. This cannot be done without investing in increasingly sophisticated techniques that result in increased production costs and energy consumption. The storage of products is one of the main stages of the production process. Drying is one of the conservation approaches. In the field, you usually see food scattered on the flat surface such as raisins, figs, wheat, or apricots, sun exposure for drying. However, this approach has several drawbacks. It depends on the weather or climatic conditions and involves more space and prolonged exposure to sunlight. [7].

On a commercial scale production limitations under sun-drying includes the attack of birds, rodents, and other animals. Quality degradation due to exposure to direct solar radiation, rain or dew, dirt contamination, or debris. Besides these disadvantages, there are 
more chances of microorganism growth and insect infestation by lacking non-uniform drying [8].

The availability of solar energy in tropical and sub-tropical zones has increased its potential for different applications because it is a sustainable source of energy. Sun-drying increases the chances of contamination such as contamination by dust, animals, birds, and insects. The chances of microbial and enzymes deterioration increases in sun-drying due to widespread period of drying under the sun [9].

Fruits and vegetable solar drying permit storage for a longer period without deterioration. This advanced technology is viable and valuable. Furthermore, solar drying uses less time to dry and saves energy. According to the experiment, the approximate amount of solar energy generated on the earth's surface is $4.30 \times 1020 \mathrm{Joule} / \mathrm{h}$, which is greater than the total consumption of energy by humans in a year of $4.1 \times 1020$ J [10].

Drying is a complex procedure that changes the characteristics of food in several means. Most of the changes in the material produced by drying are detrimental to the quality of the end product. The drying system of foodstuff needs to be designed in an integrated manner, taking into account the processes of pre-drying and postdrying. Drying is carried out by preparing the material appropriately selected to obtain a product of better quality. Drying is a common way of handling food and creating a yield that is not available with other processing methods. It requires a deep understanding of the advantages and disadvantages of the drying process to design the process and to obtain a product of the required quality [11]

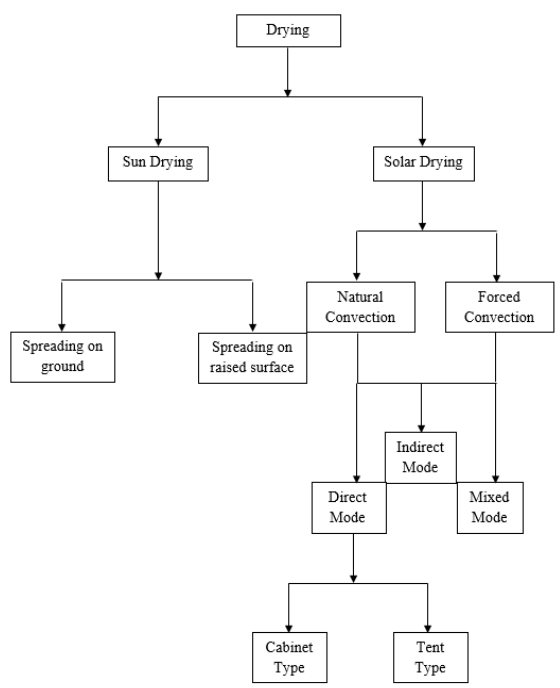

Fig. 1: SCHEMATIC DIAGRAM OF DRYING (SUN AND SOLAR DRYING)

Transfer of heat must be occurred due to the difference in temperature of the agricultural commodity with atmosphere and mass transfer due to elimination of water from inside the food commodity by the surrounded surface through the evaporation process. [12].

For making a process of drying successful, a sufficient amount of heat must be there to withdraw moisture without affecting the internal structure of the product by cooking. Adequate circulation of dry air should be supplied to transfer the moist air from the drying compartment. [13].

In a direct solar dryer, a structure with transparent covers and side panels is used to keep the agricultural produce to be dried. Solar radiation absorbed by the product and the internal surfaces of the drying chamber generates heat thus increasing the temperature of the crop and its enclosure. These types of dryers are suitable for places where direct sunlight can be received for longer periods during the day [14].
Keeping in view the aforesaid details it is necessary to develop a machine to minimize the waste of fruits and vegetables in the season of abundance so that those may be used in the season of scarcity. The existing study is planned to meet up the following objectives

To develop, fabricate and optimize the working parameters of the indirect multi-portioned type solar dryer for different agricultural produce

To minimize post-harvest damages and improve the handling of agricultural commodities

To assess the performance of the dryer by varying inlet velocity of air on temperature, final moisture of the product, drying period, and drying rate

\section{MATERIALS AND METHODS Design features}

The design features of the dryer are based upon different considerations. The design parameters of the system include the climatic conditions of the location where tests were carried out, drying time required to dry the specific agricultural commodities, amount of water to be removed from the produce, how much heat is required to remove or eliminate water from produce, the temperature of the air and most important is the flow rate of air within the system to get the desired level of significant.

\section{Temperature}

The recommended temperature of drying for different agricultural products such as fruits and vegetables is $38-55^{\circ} \mathrm{C}$. Temperature exceeding this limit results in caramelization (browning due to sugar) during drying. The average temperature of $46^{\circ} \mathrm{C}$ for drying was taking into account for the development of the drying system [15].

\section{Collector Sizing}

There is a specific relation between the length and width of the dryer, that if the width of the dryer is 1 meter then the length of the collector unit should be 2 meters. The length to width ratio is expressed as 1-2. Thus, during construction of the solar dryer was based on this ratio [16].

\section{Solar collector tilt angle}

The ideal inclined angle should be equal to the latitude of the location and addition of $15{ }^{\circ} \mathrm{C}$ in winter season and subtraction of 150 in summer season [17]. According to the literature, the latitude of Faisalabad is $31.45^{\circ} \mathrm{N}$. Thus, the construction location of the solar dryer was Faisalabad so, a solar collector tilt angle of $16^{\circ} \mathrm{C}$ was considered for the summer season and $45^{\circ} \mathrm{C}$ was considered for the winter season.

\section{Flow rate requirements}

The air velocity for the solar dryer varies from $0.52 \mathrm{~m} / \mathrm{s}$ to $5.10 \mathrm{~m} / \mathrm{s}$. The airflow requirement depends upon the type of commodity and temperature. During dryer development, the velocity variations were considered. Generally, the gap between the transparent cover and the absorber plate must be $1 / 15$ to $1 / 20$ to the collector length [15].

\section{Rate of drying}

Drying rate is well-defined as the quantity of moisture removed divided by time (Dhanushkodi et al., 2014).

Drying Rate $=\frac{\text { Wi- WA }}{2}$

Where,

$\mathrm{W}_{\mathrm{i}}=$ Initial weight of the sample, $\mathrm{g}$ or $\mathrm{Kg}$

$\mathrm{W}_{\mathrm{d}}=$ Weight after drying, $\mathrm{g}$ or Kg

$\mathrm{t}=$ Time of drying, hours

\section{Moisture content}

Moisture content is taken as most of the significant characteristics of the material to be dried, which shows the performance of the 
system. Wet basis moisture content is described as; the amount of moisture present in a wet sample [18].

Moisture content $(w, b)=\frac{\text { wright of wrter }}{\text { weikht of the moiat migls }} \times 100$

Moisture content on a dry basis is calculated by the relation given by [19]

Moisture content (d.b) $=\frac{\text { wright of wrtsx }}{\text { wrixht of } d r y \text { wlid }} \times 100$

\section{Instruments Used for Data collection}

Instruments that were used for data collection include a thermometer, pyranometer, anemometer, digital weighing balance, microwave oven, and manual slicer.

There are different types of equipment used for power supply to the fans such as; step down transformer, three slid switches, pushbuttons, transistors, and copper wire.

\section{Solar dryer construction}

An indirect solar dryer was developed and fabricated and had four major parts; a solar collector, air storage part, a drying chamber, and a duct for exiting moist air (chimney). The energy source considered for solar collectors was the sun.

\section{Solar collector}

The collector of the dryer consisted of three major parts; transparent cover, metal sheet as an absorber, insulation to prevent heat loss, and a wooden frame to support all these parts in assembled condition. The transparent cover of the dryer was cut from a clear glass of $5 \mathrm{~mm}$ thickness. A metallic sheet with a black painting surface for absorbing the energy passing through the glass was used of $1 \mathrm{~mm}$ thickness. The gap between the metal sheet and covering glass kept $0.15 \mathrm{~m}$ ( $0.5 \mathrm{ft}$.). A wooden sheet of $7 \mathrm{~mm}$ thickness was used below the absorber plate to provide support as well as to decrease heat loss from the sun-operated absorber. The insulating material of $3 \mathrm{~mm}$ was used below the absorber sheet. The dimensions of the developed collector were $1.83 \times 0.91 \mathrm{~m}(6 \times 3 \mathrm{ft}$. $)$ length and width respectively. The tilt angle or the declination angle of the solar collector (absorber plate) was adjusted according to season variation and latitude of Faisalabad that $15^{\circ} \mathrm{Cand} 45^{\circ} \mathrm{C}$. A fan assembly has been used that control the airflow rate inside the solar collector.

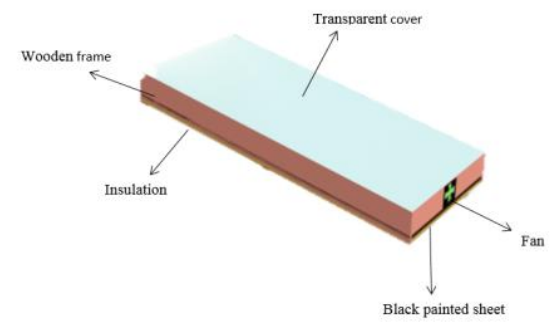

Fig. 2: Solar Collector Isometric View

\section{Air storage chamber}

This part of the dryer was designed to collect the warm air coming from the collector unit and supply this warm air to the drying compartment. The air storage chamber was constructed of MDF (medium-density fireboard) plywood of $7 \mathrm{~mm}$ thickness having dimensions $0.91 \times 0.30 \times 0.91 \mathrm{~m}(3 \times 1 \times 3 \mathrm{ft}$. $)$ length, width, and height respectively.

\section{Drying chamber}

The drying enclosure for placement of agricultural commodities to be dried was made of wood material having $7 \mathrm{~mm}$ thickness. The dimensions of the drying chamber were set to $0.91 \times 0.61 \times 0.91 \mathrm{~m}$ $(3 \times 2 \times 3 \mathrm{ft}$.) length, width, and height respectively. This drying chamber was further divided into three different parts (portions) such as a sub-drying chamber in which trays will be placed. Each portion of the drying chamber was fixed with a fan assembly and a separate exit for the removal of moist air. The ongoing drying process in the respective portion was not interlinked with each other. The drying trays for the loading of product in the drying chamber were made of stainless steel having dimensions $0.91 \times 0.61$ $\mathrm{m}(3 \times 2 \mathrm{ft}$.). There was a door at one side of this unit for loading and unloading of the un-dry and dried commodities.

\section{Chimney}

The chimney was used for the removal of moist air from the drying chamber. The chimney was constructed of an MDF sheet with a 7 $\mathrm{mm}$ thickness. The total length of the chimney was $0.91 \mathrm{~m}(3 \mathrm{ft})$. The other dimensions for the chimney were $0.18 \times 0.18 \mathrm{~m}(0.6 \times 0.6 \mathrm{ft}$. $)$ length and width respectively. The chimney was attached at three points of the drying chamber i.e. each exit of the drying chamber. The top of the chimney was covered properly to prevent the entry of foreign particles/substances into the chimney.

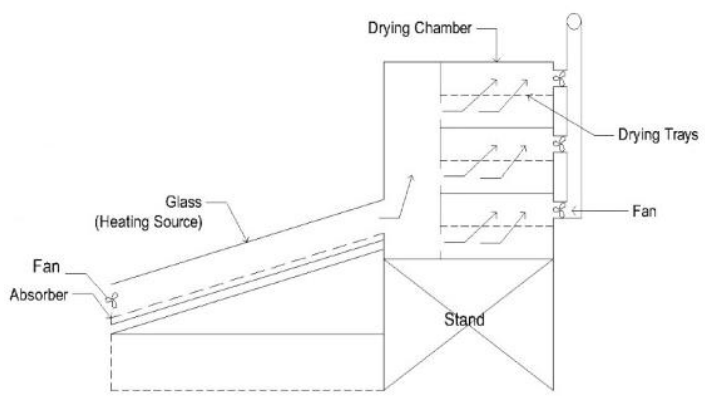

Fig. 3: 2D Diagram Of Solar Dryer

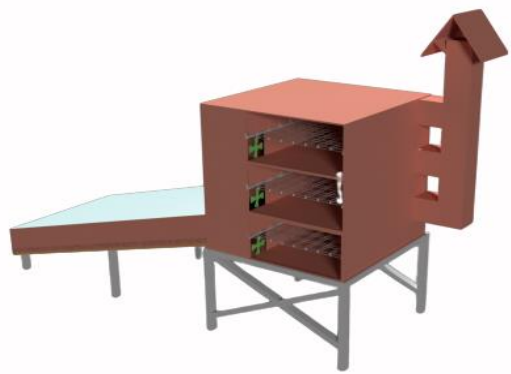

Fig. 4: Solar Dryer Isometric View 1

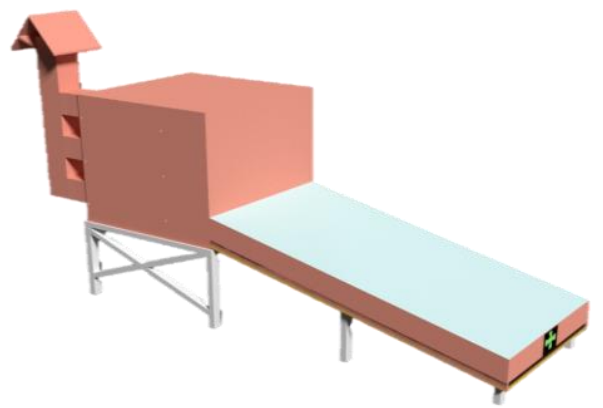

Fig. 5: Solar Dryer Isometric View 2

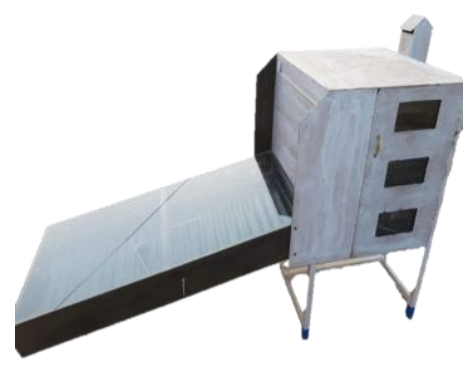

Fig. 6: Multi-Portioned Type Solar Dryer Structural View 


\section{RESULTS AND DISCUSSION}

After completing all the procedures and methods of dryer construction, the performance of the dryer was tested by conducting different trials. A drying test was conducted to check the performance of the dryer by using fresh potatoes. The potatoes were cleaned, washed, peeled, and then sliced into equal thickness to get uniform drying of the product. The sliced potatoes were loaded on each tray in the drying chamber. Equal weight of the sample was loaded in each drying portion. The initial moisture of the product on a wet basis was calculated about $80.5 \%$ of the sample that was chemically treated with sulphiting and blanching process.

\section{Distribution of Temperature}

The figure shows the temperature variation at different stages of the dryer during the testing hours from 11:00 AM to 03:00 PM. The dark horizontal strips indicate the collector temperature and the dark vertical stripes indicate the ambient temperature. A maximum collector temperature of $75^{\circ} \mathrm{C}$ was attained when the ambient temperature was recorded as $38^{\circ} \mathrm{C}$. The maximum elevation in temperature by the collector was $37^{\circ} \mathrm{C}$ at $12: 00 \mathrm{PM}$. However, the average temperature of $51.8^{\circ} \mathrm{C}, 51.5^{\circ} \mathrm{C}$, and $50.6^{\circ} \mathrm{C}$ was recorded at the top, middle, and bottom portion of the dryer respectively as shown in the table 1 below.

Table 1: Distribution of Temperature Over Collector, The Top Portion, Middle, And Bottom Portion

\begin{tabular}{cccccc}
\hline $\begin{array}{c}\text { Sunshine } \\
\text { Hours }\end{array}$ & $\begin{array}{c}\text { Ambient } \\
\text { Temp. } \\
\left({ }^{\circ} \mathbf{C}\right)\end{array}$ & $\begin{array}{c}\text { Collector } \\
\text { Temp. } \\
\left({ }^{\circ} \mathbf{C}\right)\end{array}$ & \multicolumn{3}{c}{ Dryer Inlet Temperature $\left({ }^{\circ} \mathbf{C}\right)$} \\
Top & Middle & Bottom \\
\hline 11:00 AM & 37 & 72 & 49 & 49 & 48 \\
12:00 PM & 38 & 75 & 52 & 51 & 50 \\
1:00 PM & 39 & 71 & 54 & 53.5 & 53 \\
2:00 PM & 39 & 67 & 53 & 53 & 52 \\
3:00 PM & 39 & 61.5 & 51 & 51 & 50 \\
Average & 38.4 & 69.3 & 51.8 & 51.5 & 50.6 \\
\hline
\end{tabular}

The dark horizontal strip, narrow vertical strip, and narrow horizontal strips show the temperature elevation at the top, middle, and bottom portion of the dryer respectively.The average temperature showed a small variation due to the difference in airflow at these three portions of the solar dryer.

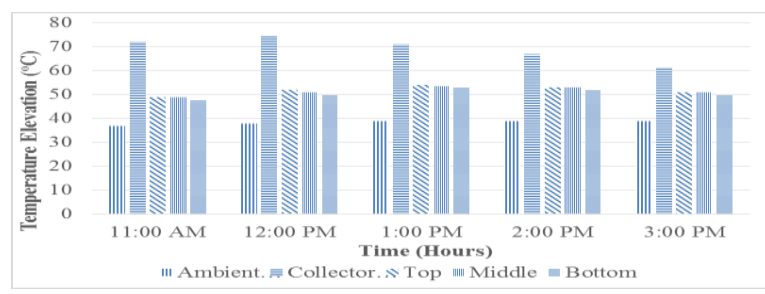

Fig. 7: Distribution of Temperature

\section{Drying rate}

The initial weight of 150 grams was selected as a sample of the product to check the drying rate, moisture percentage on a wet and dry basis after each hour of the experiment. The solid weight of the sample remained the same throughout the drying process. The drying rate of all the portions was recorded after every sunshine hour to check the difference in drying rate due to the difference in temperature and velocity ranges in each portion of the drying chamber.

It had been observed during the experiment and during the calculations to find the drying rate at three different portions of the dryer that there was little variation in drying rate in all portions of the drying chamber. When the sample was placed on the tray in each portion, there was not any change in the sample because the sample weight was placed on each tray. When the time passed, the sample was taken out of the drying compartment and re-weight the sample. The loss in weight was recorded, then using the initial and final weight of the sample the drying rate was calculated. During the first sunshine hour, the drying rate was $46 \mathrm{~g} / \mathrm{hr}, 47 \mathrm{~g} / \mathrm{hr}$, and $46.5 \mathrm{~g} / \mathrm{hr}$ was observed in the top, middle, and bottom portions respectively After the second sunshine hour, the drying rate was decreased to 32 $\mathrm{g} / \mathrm{hr}, 30 \mathrm{~g} / \mathrm{hr}$, and $31.5 \mathrm{~g} / \mathrm{hr}$ in the top, middle, and bottom portion of the dryer. At the end of the drying experiment, the minimum drying rate was observed in the top, middle, and bottom portion of the system was $7.75 \mathrm{~g} / \mathrm{hr}, 8.26 \mathrm{~g} / \mathrm{hr}$, and $9 \mathrm{~g} / \mathrm{hr}$ at $04: 00 \mathrm{pm}$.

Table 2: The Drying Rate Of Three Portions of The Dryer

\begin{tabular}{cccc}
\hline Sunshine Hours & Drying rate & Drying rate & Drying rate \\
& $\mathbf{1}$ & $\mathbf{2}$ & $\mathbf{3}$ \\
\hline $\mathbf{1 1 : 0 0}$ AM & 0 & 0 & 0 \\
$\mathbf{1 2 : 0 0} \mathbf{~ M M}$ & 46 & 47 & 46.5 \\
$\mathbf{1 : 0 0} \mathbf{P M}$ & 32 & 30 & 31.5 \\
$\mathbf{2 : 0 0} \mathbf{P M}$ & 22 & 22 & 20.5 \\
$\mathbf{3 : 0 0} \mathbf{P M}$ & 12 & 12 & 12 \\
$\mathbf{4 : 0 0} \mathbf{P M}$ & 7.75 & 8.26 & 9 \\
\hline
\end{tabular}

The average drying rate was also calculated at each portion of the system, as it had been observed in the no-load test that the temperature was slightly low in the chamber where the air velocity was higher than the other compartment. The same situation was observed while calculating the average drying rate at each portion of the system. The average drying rate in the top, middle and bottom portion was recorded as $23.95 \mathrm{~g} / \mathrm{hr}, 23.85 \mathrm{~g} / \mathrm{hr}$, and $23.9 \mathrm{~g} / \mathrm{hr}$ respectively. These drying rate variations co-relate with the results obtained for the no-load test, as the minimum drying rate of $23.85 \mathrm{~g} / \mathrm{hr}$ was recorded in the middle chamber when the higher speed of air was there in the middle chamber. The maximum drying rate of $23.95 \mathrm{~g} / \mathrm{hr}$ was in the top portion when the lower velocity of air in the top portion

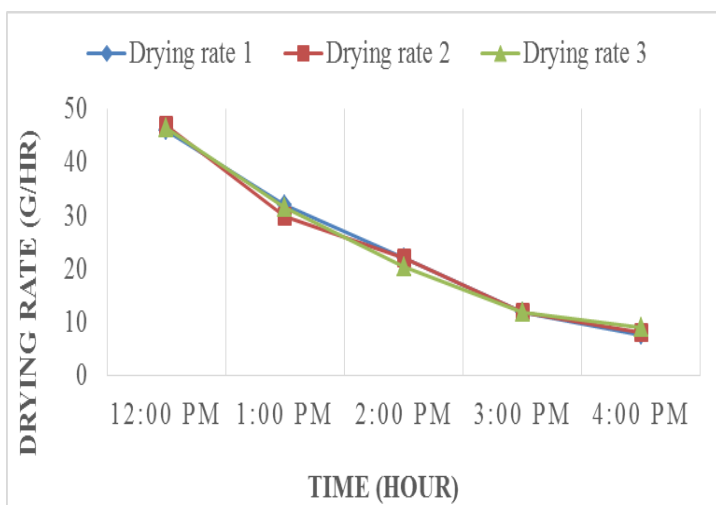

Fig. 8: Drying Rate Of Three Portions of The Dryer

\section{Quality analysis for dried product}

The quality analysis of the dried product was performed to check the percentage value of final moisture, protein, ash, and fat. These values of the product varied for each portion of the system according to their drying conditions. The minimum and maximum values of moisture were $3.31 \%$ and $4.85 \%$ respectively. The protein percentage values for the top, middle, and bottom compartment varied as $5.2 \%, 5.7 \%$, and $5.4 \%$ respectively. The ash percentage of the final dried product was recorded as $3.65 \%, 3.73 \%$, and $3.69 \%$ in the top, middle, and bottom compartments of the dryer. The fourth test was fat percentage whose values measured in the dried product were $0.4 \%, 0.46 \%$, and $0.42 \%$ respectively in product dried at the top, middle, and bottom compartment of the system.

Table 3: Quality Analysis Report Of Dried Product

\begin{tabular}{ccccc}
\hline Sr. No. & $\begin{array}{c}\text { Quality } \\
\text { attributes }\end{array}$ & $\begin{array}{c}\text { Top } \\
\text { Tray } \\
\mathbf{1}\end{array}$ & $\begin{array}{c}\text { Middle } \\
\text { Tray } \\
\mathbf{2}\end{array}$ & $\begin{array}{c}\text { Bottom } \\
\text { Tray } \\
\mathbf{3}\end{array}$ \\
\hline $\mathbf{1}$ & Final Moisture (\%) & 3.31 & 4.85 & 4.1 \\
\hline $\mathbf{2}$ & Protein (\%) & 5.2 & 5.7 & 5.4 \\
\hline $\mathbf{3}$ & Ash (\%) & 3.65 & 3.73 & 3.69 \\
\hline $\mathbf{4}$ & Fat (\%) & 0.4 & 0.46 & 0.42 \\
\hline
\end{tabular}

There was a little variation in the final moisture content of the dried product, this variation was due to different drying rates in different 
compartments of the dryer. The variations were also observed for all quality attributes like protein, fat, and ash percentage as shown above figure.

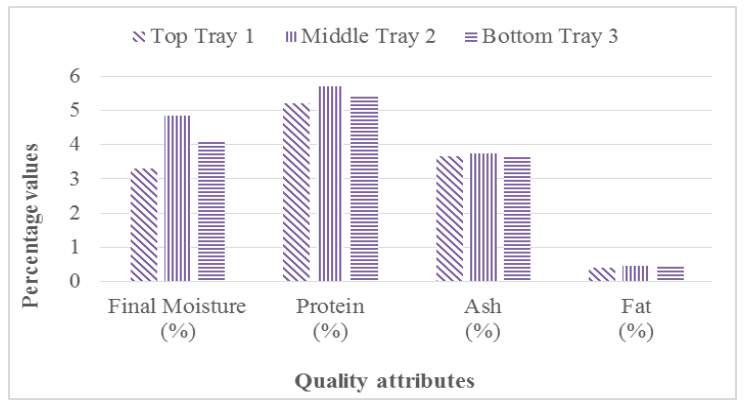

Fig. 9: Quality Analysis Of Dried Product

\section{SUMMARY}

This research work was conducted to study and evaluate the performance of the indirect multi-portioned type solar dryer. The analytical and experimental performance was thoroughly assessed for reducing the post-harvest losses of agricultural commodities. This research demonstrates the use of non-traditional methods to reduce the moisture levels present in commodities for enhancing their shelf life. The experiments conducted for the assessment of dryer's performance were administered in controlled conditions and the findings of the tests were compared with the prior research work as well. The fabrication and construction of the dryer are based on logical calculations. Also, the behavior of different commodities placed for drying under varying temperatures was observed. The motive behind the dryer's fabrication was to assist the farmers in the on-field drying of perishable commodities. The dryer is comprised of a solar collector, air storage chamber, drying chamber, and air exiting chimney. The major portion of the dryer was made using wood as it was locally available at a low cost. The research was carried out by constructing the dryer in the Food Engineering workshop. After fabrication, the dryer was operated to appraise the maximum temperature elevation by the collector using the no-load test. Also, the inlet air velocity of each drying portion was varied to assess the effect on the temperature change inside the portion and its eventual effect on the drying rate. The data obtained from the experiments revealed that the maximum temperature elevation of $37^{\circ} \mathrm{C}$ was attained during the drying experiment. The results obtained after carrying out load tests revealed that the maximum drying rate of $47 \mathrm{~g} / \mathrm{hr}$ was achieved at the air inlet velocity of $3.2 \mathrm{~m} / \mathrm{s}$. The initial moisture content of $80.50 \%$ was brought down to $3.31 \%$ in five sunshine hours of 150 gram sliced potatoes. Each portion received air at varying speeds, and it was observed that the portion receiving air at the lowest speed had the maximum temperature. The lowest temperature elevation was recorded for the portion receiving air at the highest speed. The results obtained were found satisfactory when compared with the previous findings of the researchers. The dryer was also found to be suitable for the on-field practical application for the drying of perishable commodities.

\section{CONCLUSION}

The development and fabrication of the indirect multi-portioned solar dryer were carried out and the dryer was successfully assembled and operated. The optimum air inlet speed was found to be $3.2 \mathrm{~m} / \mathrm{s}$ which resulted in attaining the maximum drying rate of $47 \mathrm{~g} / \mathrm{hr}$ of $150 \mathrm{~g}$ sample. The maximum temperature elevation of $37^{\circ} \mathrm{C}$ was recorded during the drying test. The dryer was affordable for small-scale farmers in rural areas with the total cost of PKR. $30,000 /-$

\section{REFERENCES}

1. Ahmed J, Ramaswamy HS, Hiremath N. The effect of high pressure treatment on rheological characteristics and colour of mango pulp. International Journal of Food Science \& Technology. 2005;40(8):885-95. doi: 10.1111/i.13652621.2005.01026.x.

2. Bennamoun L, Belhamri A. Design and simulation of a solar dryer for agriculture products. J Food Eng. 2003;59(2-3):25966. doi: 10.1016/S0260-8774(02)00466-1.

3. Chou SK, Chua KJ. New hybrid drying technologies for heat sensitive foodstuffs. Trends Food Sci Technol. 2001;12(10):359-69. doi: 10.1016/S0924-2244(01)00102-9.

4. Dhanushkodi S, Wilson VH, Sudhakar K. Thermal Performance evaluation of Indirect forced cabinet solar dryer for cashew drying. Am Eurasian J Agric Environ Sci. 2014;14(11):124854

5. El-Sebaii AA, Shalaby SM. Solar drying of agricultural products: a review. Renew Sustain Energy Rev. 2012;16(1):37-43. doi: 10.1016/j.rser.2011.07.134.

6. Forson FK, Nazha MAA, Akuffo FO, Rajakaruna H. Design of mixed-mode natural convection solar crop dryers: application of principles and rules of thumb. Renew Energy. 2007;32(14):2306-19. doi: 10.1016/j.renene.2006.12.003.

7. Fudholi A, Othman MY, Ruslan MH, Yahya M, Zaharim A Sopian K. Design and testing of solar dryer for drying kinetics of seaweed in Malaysia. Recent Research in Geography, Geology, Energy. Environ Biol Med. 2011:119-24.

8. Green MG, Schwarz D 2001. Solar drying technology for food preservation. GTZ publication Eschborn, Germany.

9. Hii CL, Jangam SV, Ong SP, Mujumdar AS. Solar drying: fundamentals, applications and innovations. TPR Group Publication. Singapore; 2012.

10. Kadam DM, Samuel DVK. Convective flat-plate solar heat collector for cauliflower drying. Biosyst Eng. 2006;93(2):18998. doi: 10.1016/j.biosystemseng.2005.11.012.

11. Lewicki PP. Design of hot air drying for better foods. Trends Food Sci Technol. 2006;17(4):153-63. doi: 10.1016/j.tifs.2005.10.012.

12. Medugu DW. Performance study of two designs of solar dryers. Arch Appl Sci Res. 2010;2(2):136-48.

13. Mercer DG, Eng P. An intermediate course in food dehydration and drying. Ontario, Canada: Department of Food Science, University of Guelph; 2007.

14. Mujumdar AS, Devahastin S. Fundamental principles of drying. Exergex, Brossard, Canada. 2000;1(1):1-22.

15. Olaniyan AM. Development of a small scale orange juice extractor. J Food Sci Technol. 2010;47(1):105-8. doi: 10.1007/s13197-010-0002-8, PMID 23572610.

16. Rajkumar P, Kulanthaisami S, Raghavan GSV, Gariépy Y, Orsat V. Drying kinetics of tomato slices in vacuum assisted solar and open sun drying methods. Drying Technol. 2007;25(78):1349-57. doi: 10.1080/07373930701438931.

17. Sanni LO, Onadipe-Phorbee O, Alenkhe EB. Low-cost sustainable cassava drying technologies in West Africa: A compendium of information, design, fabrication and pilot testing. Abuja, Nigeria: International Institute of Tropical Agriculture; 2012.

18. Scanlin D. Indirect, through-pass, solar food dryer. Home Power. 1997; February.

19. Tibebu TB. Design, construction and evaluation of performance of solar dryer for drying fruit [doctoral dissertation]; 2015.

20. Weiss W, Buchinger J. Solar drying. AEE INTEC Publication, A8200 Gleisdorf, Feldgasse. Vol. 19; 2012. 